\title{
Diesel Engine Selection on Locomotive Using AHP Methods
}

\author{
Ivan PETROVIĆ*, Željko HEDERIĆ, Marinko STOJKOV, Ivan SAMARDŽIĆ
}

\begin{abstract}
The paper presents selection of diesel engines for diesel hydraulic locomotives of 600 horsepower (478 kW). DHL 600 are locomotives intended for manoeuvring, towing cargo of up to 1000 tones, they are suitable for railways with no electrical contact grid, and due to their characteristics, they are classified as locomotives of medium strength intended for manoeuvring within railway stations and industrial terminals, forming and dismantling freight trains, as well as for towing lighter freight trains for shorter distances from the station where they are positioned for operating. DHL are primarily appointed for service within the railway station and belonging industrial terminals, and for towing lighter trains for shorter distances from the appointed station. The paper describes the selection of diesel engine using AHP method, based on economic criteria which have great influence on cost-effectiveness and financial feasibility.
\end{abstract}

Keywords: AHP method; diesel engine; diesel locomotive; Expert Choice

\section{INTRODUCTION}

In accordance with the methods of power transmission in the HŽ Cargo d.o.o. rolling stock, there are two main types of diesel towing vehicles: electrical diesel towing vehicles and hydraulic diesel towing vehicles [1]. Current tendency in towering vehicles production can only be realised by constructing diesel engines with appropriate power. DE manufacturers work intensively on research in order to manufacture the most powerful DE for the market, i. e. for the railways. On the other hand, the railways need to choose from the vast number of various available engines, DEs for their locomotives which satisfy operation conditions [2].

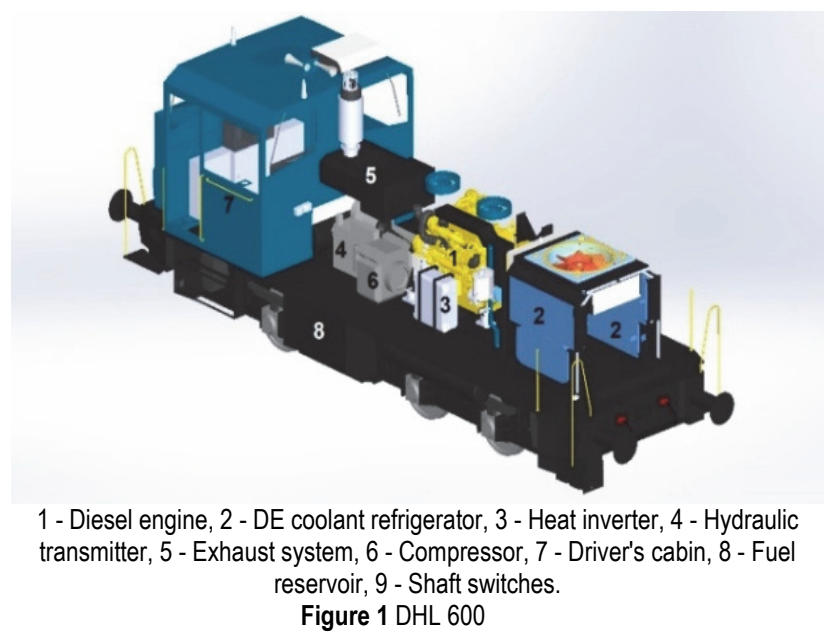

\section{DIESEL ENGINE SELECTION CRITERIA}

Railways define some criteria that need to be fulfilled by engines, so that the railways gain benefits that are expected during the exploitation of diesel engines:

Engine power: Railway transport develops from day to day. More and more powerful locomotives are required for efficient towing. Locomotive power can be improved by installing two DEs, but it turned out to be less costeffective than towing trains using locomotives with one engine incorporated.

Engine family: Engine family implies incorporating same main elements (pistons, piston rods, cylinder heads, bearings) into engines with different rated power, i. e. into engines with different cylinder numbers. In this way, a bigger number of different (by construction, purpose and power) diesel vehicles is obtained with a great number of same DE elements, which enables cheaper procurement of spare elements and maintenance.

Cost-effectiveness: Cost-effectiveness implies low specific consumption of fuel and lubricant, i.e. consumption expressed in grams per $\mathrm{kW} / \mathrm{h}(\mathrm{g} / \mathrm{kWh})$. It is one of the most important factors, because even the slightest saving percentage of fuel has a great positive impact on the general cost balance, as a large amount. A bigger part of exploitation costs is constituted by operating energy costs. Engines are considered cost-effective if they have specific consumption:

$g_{e}=200-220 \mathrm{~g} / \mathrm{kWh}$

Dimensions and weight: Every increase in power causes an increase in engine's dimensions and weight, which presents a problem in incorporating the engine into the locomotive. That is why it is important that the engine can be incorporated into the locomotive and that the expected axle pressures, which are still pretty low for many railway administrations, are reached. Nowadays, DE with specific weight below $6,5 \mathrm{~g} / \mathrm{kW}$ are manufactured, which means that there are engines with $4000 \mathrm{~kW}$, weighting below 25 tones.

Price: Purchase price is an important factor in DE selection. With a compact DE construction, lower price can be obtained.

Ease of maintenance: Nowadays, great attention is given to constructing engines which are, among other characteristics, easy to maintain in operation. This easiness needs to be reflected in a small scope of works during every single inspection and setting, large time intervals between control and technical inspections and accessibility of individual elements.

Time intervals between main repairs: Diesel engines used in railways are expected to have the largest possible time interval between main repairs. Modern manufacturing technology enables producing DEs with the interval between two main repairs reaching between 20000 and 30000 working hours. 
Table 1 Overview of diesel engines installed into DHL 600 [2]

\begin{tabular}{|c|c|c|c|c|c|c|c|c|c|}
\hline No & $\begin{array}{l}\text { Diesel engine } \\
\text { type }\end{array}$ & $\begin{array}{l}\text { Manufacturer- } \\
\text { country }\end{array}$ & $\begin{array}{l}\text { Installed into } \\
\text { diesel vehicle }\end{array}$ & $\begin{array}{c}\text { Power } \\
P_{e} / \mathrm{kW}\end{array}$ & $\begin{array}{l}\text { Rotations } \\
\mathrm{r} / \mathrm{min}\end{array}$ & $\begin{array}{l}\text { Number of } \\
\text { cylinders }\end{array}$ & $\begin{array}{c}\text { Specific } \\
\text { weight } \\
\mathrm{kg} / \mathrm{kW}\end{array}$ & $\begin{array}{c}\text { Specific fuel } \\
\text { consumption } \\
\mathrm{g} / \mathrm{kWh}\end{array}$ & $\begin{array}{c}\text { Number of } \\
\text { strokes }\end{array}$ \\
\hline 1 & JW 600 & $\begin{array}{c}\text { Jenbach } \\
\text { Austria }\end{array}$ & 732 & 400 & 1500 & V 12 & 6,33 & 251 & 2 \\
\hline 2 & $16 \mathrm{Jv} 17 / 24$ & Ganz Hungary & 811 & 367 & 1050 & V16 & 12,6 & 245 & 4 \\
\hline 3 & MGO V12 A & $\begin{array}{c}\text { SACM - ĐĐ } \\
\text { France, } \\
\text { Yugoslavia }\end{array}$ & 733,740 & 400 & 1500 & V12 & 9,5 & 288 & 4 \\
\hline 4 & $\begin{array}{c}\text { Cat } \\
3412 \mathrm{E}\end{array}$ & $\begin{array}{l}\text { Caterpillar } \\
\text { USA }\end{array}$ & $21323 X X$ & 478 & 1500 & V12 & 5,46 & 186 & 4 \\
\hline 5 & $\begin{array}{c}\text { Cat } \\
\text { C18 } A_{\text {cert }}\end{array}$ & $\begin{array}{l}\text { Caterpillar } \\
\text { USA }\end{array}$ & $2132600-5$ & 490 & 1500 & V12 & 3,53 & 175 & 4 \\
\hline
\end{tabular}

Work safety: In railway transportation, complete safety and operation with as few failures as possible is expected from the railway vehicles.

Manufacturers of railway diesel engines work mainly on the following characteristics:

- Power improvement

- Cost-effectiveness improvement

- Engine family development

- Lowering noise and vibration

Engine power. Effective engine power depends on multiple factors (cylinder section, cylinder stroke, number of revolutions, effective pressure etc.). By adopting appropriate parameters, diesel engines with 3000 - 4000 $\mathrm{kW}$ are manufactured today for railway needs. The number of revolutions of a crankshaft varies from $700-1500 \mathrm{r} / \mathrm{min}$ in four-stroke engines, from $650-1100 \mathrm{r} / \mathrm{min}$ in thermally loaded two stroke engines. Increasing the number of revolutions in an engine with given power and effective pressure decreases the engine's dimensions and length, but increases average piston speed, which limits the engine's life span.

The number of cylinders in locomotive diesel engines ranges from 6 to 20. In diesel engines of 20 cylinders difficulties arise: due to the length of the engine constructing crankshaft is difficult, risk of vibration occurs and maintenance is impractical.

\section{MAINTENANCE}

Maintenance is a combination of all technical, administrative and managing procedures within the lifespan of a certain element with a goal of maintaining or restoring the element to a state which enables it to perform the required function, [8-10]. Goals towards which maintenance activity is oriented are mutual to almost all technical devices and systems, and those are: work safety, greater availability, greater reliability and reducing expenses. In regard to addressing the malfunction, there are three main types of maintaining technical devices and systems: corrective maintenance, preventative maintenance and preventative-corrective maintenance.

Preventative-corrective maintenance or maintenance according to condition, is defined as an array of activities that prevent the occurrence of malfunctions. They are being undertaken in accordance with the information on the state of the facility or its components, i. e. based on results of diagnostic examination of the machines $[8,11]$.

\subsection{Types of Maintenance}

Corrective maintenance implies repairing systems after they have suffered a malfunction, i. e. after they no longer perform the required function. Corrective maintenance implies an array of procedures on the said system which is unable to operate in order to restore its functionality to the previous level, i. e. to full operability.

Advantages of such an approach are the lowest cost and greatest exploitation of system resources (those resources are used for as long as they are functioning) [8].

Preventative maintenance implies caring for and repairing the system in order for it to remain within satisfactory operating characteristics with the means of monitoring the system, detecting and correcting a potential malfunction before such occurs. Preventative maintenance implies prevention, i.e. preventing the malfunction. The goal is to have a system that will not suffer failures, and that is ensured by periodically ensuring its properties and functions [8].

Maintenance according to condition implies monitoring degradation of particular parts in order to prepare their replacements before the malfunction occurs.

\section{CALCULATING TOWING FORCES}

Such a way of maintenance enables timely reactions and faster system restoration. The only time spent is used to fix or replace the faulty part. In order to move the train's mass along a particular railway in a certain timeframe, towing force is needed [2]:

$P=F \cdot v \cdot 10^{-3}=\frac{F \cdot V}{3600}$

where: $F$ - towing force, $v$ - driving speed, $V$ - driving speed.

Locomotive's towing force must be selected in such a way that it overcomes towing resistance, and that it can accelerate locomotives and wagons. Towing force must correspond to the following formula:

$F=10^{3} \cdot m_{t r} \cdot a+W$

where: $m_{t r}$ - train mass, $a$ - train acceleration, $W$ - towing resistance.

Towing resistance are forces that act opposite of the moving direction, i.e. opposite of the train's direction, and they consist of movement resistance $\left(W_{k}\right)$, slope resistance $\left(W_{i}\right)$, turn resistance $\left(W_{r}\right)$, and acceleration resistance $\left(W_{a}\right)$. 


\section{MODELING SYSTEM FOR SELECTING OPTIMALTYPES OF DIESEL ENGINES}

In order to optimize maintenance, it is proposed to reduce the number of different types of diesel engines. Making the right decision significantly contributes to optimizing the maintenance of resources in complex systems such as railway organizations. In doing so, the proper selection of devices to be maintained and used in different situations plays an important role. Even small savings that arise from the proper application and maintenance of an individual device contribute significantly to the overall savings that arise in the overall system.

Therefore, in large systems, methods that optimize the application of resources are continuously explored.

In railway organizations, resources that are specially produced for railway use are used and are included in the means with extended lifespan.
For example, the lifespan of certain types of electric generators can be 30 years or more. Due to the long service life and continuous renewal of resources, a large number of different types often appear in railway organizations. In order to give priority to the use and thus maintenance of certain types of diesel engines, it is necessary to consider a number of different criteria and make the right decisions. In case of making wrong decision, significant losses occur, because of the large number of resources. This should be especially kept in mind when writing off equipment. To avoid such flat-rate decisions, the modeling of the system for optimal selection of diesel engines was approached, using multicriteria analysis.

One of the frequently used methods is the AHP method (Analytical Hierarchical Process) [20-22] which is applied and described below:

Table 2 Saaty's scale of relative importance [19]

\begin{tabular}{|c|c|c|}
\hline Importance & Definition & Explanation \\
\hline 1 & Equally important & Two criteria or alternatives equally contribute to the goal \\
\hline 3 & Weak importance & Based on experience and evaluation, a moderate advantage is given to one criterion or alternative over \\
\hline 5 & Strong importance & Based on experience and evaluation, one criterion or alternative is strongly favored over another \\
\hline 7 & Demonstrated importance & One criterion or alternative is strongly favored over another \\
\hline 9 & Absolute importance & $\begin{array}{c}\text { Evidence that favors one criterion or alternative over another is confirmed with the highest possible } \\
\text { order of affirmation }\end{array}$ \\
\hline $2,4,6,8$ & Intermediate values & \\
\hline $1,1-1,9$ & Decimal values & $\begin{array}{c}\text { When comparing activities that are close in importance to each other, decimal values are needed to more } \\
\text { accurately express the difference in their importance. }\end{array}$ \\
\hline
\end{tabular}

\subsection{Analytical Hierarchy Process (AHP)}

The Analytical Hierarchical Process or AHP method was created by the famous Professor Thomas L. Saaty in the 1970s. The method is one of the best-known and most frequently used methods for multicriteria decision-making. Its popularity stems from the fact that it is very close to the way an individual intuitively solves complex problems, breaking them down into simpler ones.

Solving complex decision problems using this method is based on breaking them down into components. These are the goal, the criteria and the alternatives.

The application of the AHP method can be explained through four steps [19]:

1. A hierarchical model of decision-making problems is developed with a goal at the top, criteria and sub-criteria at lower levels, and alternatives at the bottom of the model.

2. At each level of the hierarchical structure, the elements of the structure are compared in pairs, with the decision maker's preferences expressed using an appropriate scale that has 5 degrees and 4 intermediate levels of verbally described intensities and corresponding numerical values ranging from 1-9. Tab. 2. shows the Saaty scale for comparing the relative importance of the elements of the AHP model.

3. From the assessments of relative importance of the elements of the appropriate level of the hierarchical problem structure using a mathematical model, local priorities (weights) of criteria, sub-criteria and alternatives are calculated, which are then synthesized into overall priorities of alternatives.

4. Sensitivity analysis is performed.
The analytical hierarchical process is based on the following axioms [17]:

1. Reciprocity condition: When comparing two elements from a pair, if the first dominates over the second with intensity $x$ according to the Saaty scale, then the second element dominates over the first with intensity $1 / x$.

2. Homogeneity: A comparison only makes sense if the elements are comparable. When comparing two elements according to the Saaty scale, it must be sufficient to make a comparison by it, i.e. to make a consistent comparison table.

3. Dependency: Comparing elements in pairs from one level of the hierarchy is only possible in relation to elements from a higher level of the hierarchy.

4. Expectation: Any change in the structure of the hierarchy requires a recalculation of the priorities in this hierarchy. The mathematical model of AHP is shown below [21]. Let $n$ be the number of criteria (or alternatives) whose weights (priorities) should be determined based on an estimate of the values of their ratios denoted by $a_{i j}=w_{i} / w_{j}$. From the ratio of relative importance, the matrix of relative importance $\boldsymbol{A}$ is formed:

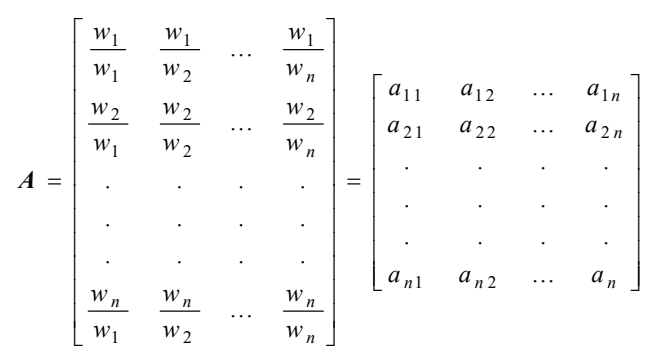


Matrix $\boldsymbol{A}$ for the case of consistent estimates for which $a_{i j}=a_{i k} \times a_{k j}$ satisfies the equation $A w=n w$, where $w$ is the priority vector:

$$
\boldsymbol{A}=\left[\begin{array}{cccc}
\frac{w_{1}}{w_{1}} & \frac{w_{1}}{w_{2}} & \ldots & \frac{w_{1}}{w_{n}} \\
\frac{w_{2}}{w_{1}} & \frac{w_{2}}{w_{2}} & \ldots & \frac{w_{2}}{w_{n}} \\
\cdot & \cdot & \cdot \\
\cdot & \cdot & \cdot \\
\cdot & \cdot & \cdot \\
\frac{w_{n}}{w_{1}} & \frac{w_{n}}{w_{2}} & \ldots & \frac{w_{n}}{w_{n}}
\end{array}\right] \cdot\left[\begin{array}{c}
w_{1} \\
w_{2} \\
\cdot \\
\cdot \\
w_{n}
\end{array}\right]=n \cdot\left[\begin{array}{c}
w_{1} \\
w_{2} \\
\cdot \\
\cdot \\
w_{n}
\end{array}\right]
$$

Since matrix $\boldsymbol{A}$ has special properties (all its rows are proportional to the first row, all elements are positive and satisfy the reciprocity property $\left.a_{i j}=1 / a_{j i}\right)$, the rank of the matrix is 1 , which is why only one of its eigenvalues is different from 0 and is equal to $n$ (all other eigenvalues are equal to 0). If the matrix $\boldsymbol{A}$ contains inconsistent estimates, the weight vector $\boldsymbol{w}$ can be obtained by solving the equation:

$\left(\boldsymbol{A}-\lambda_{\max } I\right) \cdot w=0$

provided that $\Sigma w_{i}=1$,

where $\lambda_{\max }$ is the largest eigenvalue of matrix $\boldsymbol{A}$.

Due to the properties of matrix $\boldsymbol{A}, \lambda_{\max } \geq n$ holds, and the difference $\lambda_{\max }-n$ is used in measuring the consistency of estimates. Using the consistency index $C I=\left(\lambda_{\max }-n\right) /$ $(n-1)$, the consistency ratio $C R=C I / R I$ is calculated, where $R I$ is a random index, i.e. the consistency index for matrices of order $n$ of randomly generated comparisons in pairs.

Table $3 \mathrm{RI}$ values of random indexes [16]

\begin{tabular}{|c|c|c|c|c|c|c|c|c|c|c|}
\hline$n$ & 1 & 2 & 3 & 4 & 5 & 6 & 7 & 8 & 9 & 10 \\
\hline$R I$ & 0 & 0 & 1 & 0,89 & 1,11 & 1,25 & 1,35 & 1,4 & 1,45 & 1,49 \\
\hline
\end{tabular}

\subsection{Selection of Optimal Diesel Engines According to Economic Criteria}

A model based on multi-criteria decision-making has been developed for the selection of optimal diesel engines. The AHP method was applied for decision making. The model is particularly suitable for application in complex systems such as railway organizations where long-term device status data is recorded and stored.

The work orders in question are documents used in technical workshops. They contain detailed information on the implementation of device maintenance. One of the first documents of the work order is the record of receipt of device for overhaul. It contains data on the device condition upon receipt for overhaul, with detailed information observed by the user. After that, inspection is usually carried out in the assembled state, and if necessary, the diesel engine is disassembled into assemblies and elements, and fault diagnosis of the diesel engine is performed. Based on fault diagnosis, spare parts are taken from the warehouse, and parts that are not in the warehouse are ordered through contracted suppliers. After delivery of the parts, the diesel engine is assembled and tested.

After the examination, the device is handed over to the user, and all steps from receipt to delivery of the device are recorded in detail through the work order. The model is targeted so that as much information as possible can be obtained from the above documents, and information not listed in the documents can be obtained by conducting simpler tests that can be carried out with available equipment within the railway organization.

The ExpertChoice software package was used to select the optimal diesel engines where more criteria appear. This package is often used in selecting optimal solutions [2022].

Based on the identified issues in the maintenance of electric generators, the goal, criteria and alternatives have been identified. From an economic point of view, five criteria are included for the selection of optimal diesel engines.

Criterion 1: Fuel consumption per obtained $478 \mathrm{~kW}$ (600) at a nominal load of 1000 tons.

Diesel-hydraulic locomotives are powered by internal combustion engines. They convert the chemical energy of the fuel into mechanical work, which is transmitted to the axle assemblies by cardans and gearbox. Economically speaking, according to this criterion, diesel engines that deliver more mechanical energy with the same amount of fuel consumed are more cost-effective. The model takes into account the same type of fuel, meaning that the price of fuel is the same. For this reason, the relationship between obtained mechanical energy and the amount of fuel consumed is considered. Otherwise, the ratio of the obtained mechanical energy and the price of consumed fuel would be considered. This criterion is based on data on fuel consumption at the so-called diesel engine load.

In this case, a certain type of diesel engine consumes a minimum amount of fuel per $\mathrm{kWh}$ of mechanical energy delivered. To make it more clear, the fuel consumption of DHLs powered by diesel engines at rated loads ranges from 200 to $250 \mathrm{kWh}[2,3]$. While reducing the load, i.e. by reducing the output power of the generator, the fuel consumption per HP of the obtained mechanical energy increases.

Criterion 2: Costs of regular service, which are observed for 1000 operating hours of the drive motor. The period between the two services is defined by the manufacturer, and in exceptional cases a decision may be made by the user in which the implementation period is changed. This generally rarely happens, and if it does, detailed research is conducted before a decision is made. As stated, this criterion considers a period of 1000 operating hours.

For services that are carried out after a larger number of working hours, higher quality oils are generally used, the price of which is much higher. In addition to oil, the price of other parts that change, filters etc. is generally higher. Total costs are the sum of material costs, parts and labor costs. The price of replaced parts and consumables, as well as the price of one working hour work can be determined relatively easily and accurately.

Criterion 3: Costs of corrective maintenance in the period of 2000 working hours. 
Different types of diesel engines also have different degrees of reliability [2], i.e. they have different failure properties. Some types of diesel engines will break down more often and the need for corrective maintenance will arise, and some less often. Fault frequency itself does not have to be decisive, because fault severity, i.e. the costs incurred during corrective maintenance, is also important. Corrective maintenance costs also include the sum of material costs and labor costs. In this case, the costs incurred due to device idleness are not calculated.

Criterion 4: Storage costs that include the costs of conservation and deconservation of the asset.

Costs incurred in re-commissioning the asset are added to these costs. Assets that are not in use are kept in strategic reserve warehouses. Conservation is carried out on diesel engines that have been out of use for more than three months. Conservation can be short-term or long-term. Short-term conservation is carried out on diesel engines stored for 3 to 12 months, and long-term on diesel engines stored for 1 to 3 years. The process of conservation and deconservation is precisely prescribed, and is carried out by the operator, mechanic and electrician. For some types of diesel engines, the process of putting diesel engines into operation after long-term conservation is demanding and requires significant time expenditure from employees who carry out deconservation and commissioning.

Criterion 5: Service costs, incurred during the exploitation of assets.

In practice and literature, they are known as basic maintenance costs.

The service is divided into [14]:

- cleaning, washing and refueling, refilling lubricants and working media,

- daily examinations (pre-use examination, in-use examination, post-use examination),

- weekly examinations.

For diesel engines, maintenance costs can vary significantly. Older types of diesel engines must be under constant supervision of the operator because they do not have a built-in monitoring and protection system. This significantly increases maintenance costs. Newer types of diesel engines, which have a built-in protection and control system, do not have to be under control of the operator, thus reducing maintenance costs.

The period of regular services for older types of diesel engines is usually 100 working hours, and for newer types 200 and more working hours. This means that some types will need to undergo 10 services in the specified period, and some 5 and less.

As possible alternatives, 5 different types of diesel engines were considered in Tab. 4, which are marked as per table:

Table 4 Types of diesel engines installed into DHL 600

\begin{tabular}{|c|c|c|}
\hline No & Type of diesel engine & Manufacturer-country \\
\hline 1 & JW 600 & JenbachAustria \\
\hline 2 & $16 \mathrm{~J}_{\mathrm{v}} 17 / 24$ & GanzHungary \\
\hline 3 & MGO V12 A & $\begin{array}{c}\text { SACM - ĐĐ } \\
\text { France, Yugoslavia }\end{array}$ \\
\hline 4 & Cat3412E & CaterpillarUSA \\
\hline 5 & CatC18 $A_{\text {cert }}$ & CaterpillarUSA \\
\hline
\end{tabular}

Detailed characteristics are not important for the presentation of the proposed model, the procedure and the principle of operation of the model are important, so that it can be applied to other types of diesel engines. In addition to diesel engines, with minor additions, it could be applied to other means used in complex systems.

\subsection{Expert Choice software}

Expert Choice presents one of the most acceptable tools for AHP method application. Expert Choice is software representing a decision support system, which allows users to quickly develop decision support systems, both general and specific. AHP is implemented in several phases. In the initial phase, interactive creation of a problem hierarchy is conducted as a preparation of decision-making scenarios. Following that, assessment of hierarchy elements (goals, criteria, sub criteria and alternatives) in pairs is carried out in top-down or bottomup direction. At the end, synthesis of all evaluations is done and the weight coefficients of all elements of the hierarchy are established for a strictly determined model. When applying the AHP method with the supporting tools, there is a possibility of identifying and analyzing the inconsistency of decision makers in the evaluation process of the hierarchy elements. Inconsistency factor in Expert Choice tool identifies possible errors and inconsistencies in assessment. Inconsistency factor in Expert Choice tool needs to be lower than 0,1 to consider the results consistent. The results consist of a presentation of the obtained weight coefficients of criteria and sub-criteria, of the priority of variants and of the sensitivity analysis [17, 23].

The ExpertChoice software package was used to make a decision about optimal types of diesel engines. The decision is made based on above mentioned and described criteria. Information about alternatives, i.e. every diesel engine type, is available in technical documentation of device, including technical booklet, technical instructions and working orders regarding device maintenance.

The model's principle of operation and data analysis results are presented in form of screenshots from the Expert Choice software package.

\subsection{Development of a Hierarchical Decision-Making Model}

In the decision process for selection of diesel locomotive engine, the top down approach is used. First, the goal to be achieved by making a decision is defined. Then, criteria and sub-criteria differentiating the alternatives are listed. Ultimately, all the alternatives ie. desired diesel engines are listed. The following figure shows a hierarchical model of decision-making according to the top down method where the goal affects the criteria, the criteria affect the sub-criteria, and the sub-criteria affect the selection of the best alternative.

Thus, after identifying the problem in the railway company, relevant goals had to be found to achieve the decision-making aim. Since the problem in question requires a deeper analysis, deeper sub-criteria of every criterion were defined.

Thus, after identifying the problem in the railway company, relevant goals had to be found to achieve the decision-making aim. Since the problem in question 
requires a deeper analysis, deeper sub-criteria of every criterion were defined. Ultimately, all criteria, ie the corresponding sub-criteria decide which of the listed alternatives will be selected. The previous hierarchical model of a decision-making problem was translated into the ExpertcChoice tool, as shown in Fig. 3 with the goal at the top and criteria and sub-criteria on the lower level of the model.

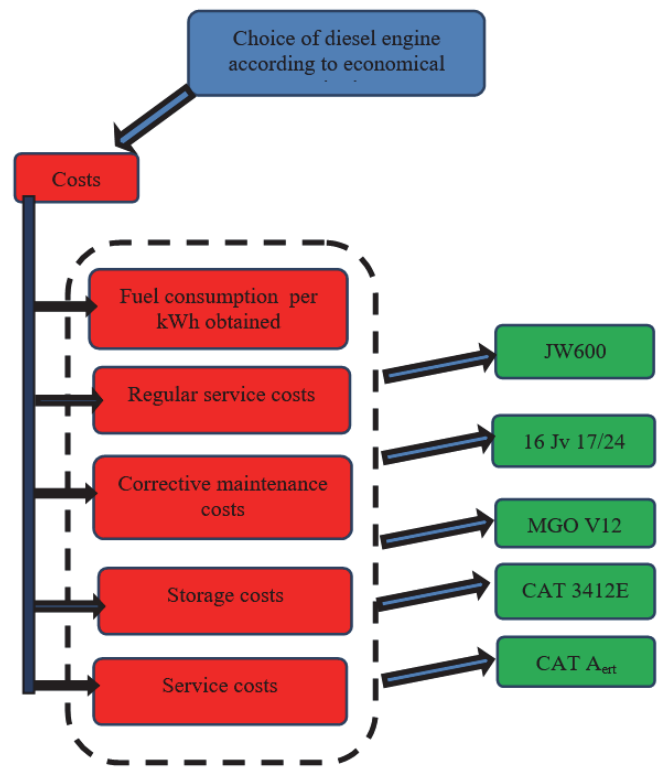

Figure 2 Development of a hierarchical model according to the top-down method

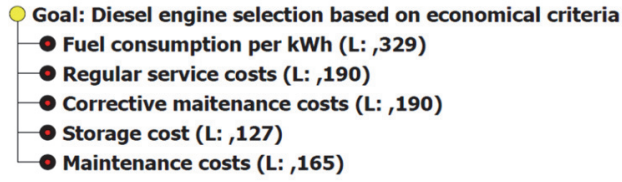

Alternatives

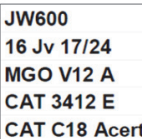

Figure 3 Hierarchical decision model

Fig. 3 presents the choice of diesel engine based on economic criteria. It shows criteria by which the choice has been made and the alternatives proposed between 5 different types of diesel engines: JW600,16 Jv 17/24, MGO V12A, CAT 3412E and CAT C18 $A_{\text {cert }}$.

\subsection{Comparing Criteria in Relation to the Goal}

The first step towards choosing the best alternative is to make a comparison of the criteria in relation to the goal in ExpertChoice. All representations were calculated in weights using the Saaty scale by numerical comparison, while the final weights of the criteria in this decisionmaking process are given in the following Fig. 4.
Priorities with resped to:

Goal: Diesel engine selection based on economical criteria

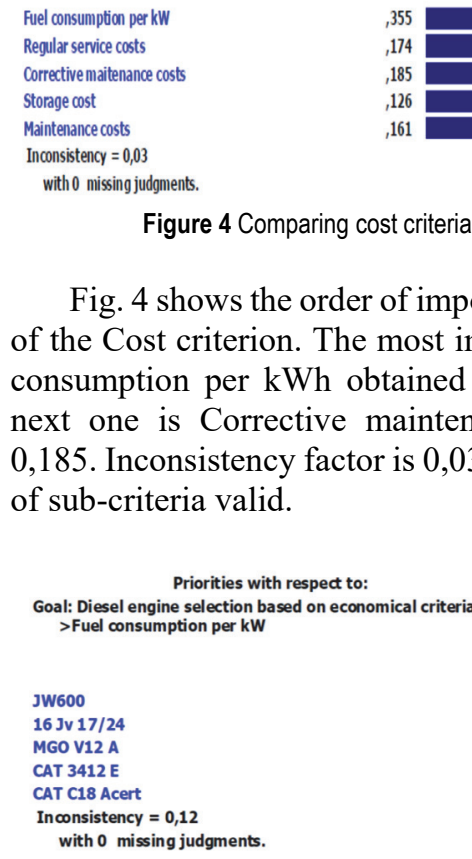
of sub-criteria valid.

Figure 4 Comparing cost criteria in relation to the goal

Fig. 4 shows the order of importance of the sub-criteria of the Cost criterion. The most important criterion is Fuel consumption per $\mathrm{kWh}$ obtained with weight 0,355 . The next one is Corrective maintenance costs with weight 0,185 . Inconsistency factor is 0,03 making this comparison

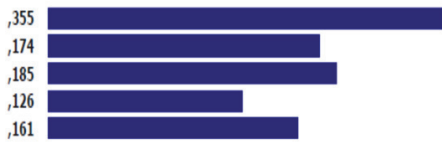

Figure $\mathbf{5}$ Calculating the priority of alternatives and choosing the best alternative

In Fig. 5 optimal types of diesel engines in terms of fuel consumption per $\mathrm{kW}$ obtained are shown in order. From the obtained results shown in the figure, it can be seen that the Cat $3412 \mathrm{E}$ is optimal in terms of fuel consumption. This is to be expected, as it is a specific diesel engine with a newer technique of injecting fuel into the diesel engine.

After comparing all the criteria, sub-criteria, alternatives and the goal in pairs, the final result of the AHP method is obtained, which is presented as the ranking of alternatives with respect to the goal. The result of AHP method for the diesel engine selection in a railway company.

It can be concluded that in this case it is also a diesel engine that is generally slightly more economical compared to other types of engines that are installed on diesel-hydraulic locomotives.

After analyzing the selection of diesel engines based on economic criteria, the results shown in Fig. 5 were obtained. From the obtained results it can be seen that $C A T$ $3412 E$ is optimal according to economic criteria.

\section{CONCLUSION}

The conducted research explored the topic of maintaining diesel engines in complex systems. It has been found that there are a large number of different types of diesel engines what makes it difficult to use and maintain.

The methodology for determining categorization parameters of diesel engines is described through the selection and elaboration of research.

The aim of this paper was to solve the problem of deciding on the selection of the appropriate diesel engine locomotive of various manufacturers. After defining the possible alternatives, criteria and sub criteria, it was necessary to perform the problem analysis using the Expert Choice software solution. 
Development of the Expert System for Fault Detection is a significant contribution to the optimization of maintenance. That is especially evident in complex technical devices, such as diesel engines, where much of the time in the maintenance process is spent on determining the technical condition or fault detection. In order to shorten the time of fault detection, an Expert Detection System has been developed whose task is to define the location of a difficult-to-detect fault, based on easily noticeable faults in the assembled state.

In order to simplify the maintenance and use of diesel engines, it is necessary to reduce a large number of different types. Previously performed tests, showing which criteria certain types of diesel engines meet, are used for the correct selection.

The selection of diesel engines was carried out using multi-criteria analysis according to economic and availability criteria.

Five different types of diesel engines were included in the selection. It has been determined that the Cat $3412 \mathrm{E}$ diesel engine is optimal according to both criteria. The same selection model can be applied to a much larger number of types and with several different criteria.

The AHP method is also used in group decision making. As the importance of criteria, sub criteria and alternatives may differ for each individual participant, the Expert Choice AHP method allows a group of decision makers to combine the results of each individual group member into one overall result.

Finally, as the conclusion of this paper, Expert Choice tool is worth using because the decision-making process is much simpler and faster than in the case of manual data processing. AHP can serve the research and engineering community as one of the best methods for subjective decision-making because sometimes it is a problem to choose the best alternative even though we have evaluated their criteria well. It is important to emphasize that the same goal or problem may have a different choice of alternatives according to importance because each person chooses the importance of various criteria and sub-criteria differently and ultimately evaluates them differently, which causes different solutions.

\section{REFERENCES}

[1] Valter, Z. (1985). Dizel-električne lokomotive. Zagreb: Školska knjiga

[2] Pajić, D. (1981). Vučna vozila. Beograd: Zavod za novinskuizdavačku i propagandnu djelatnost JŽ, 1981. god.

[3] Ožbolt, P. \& Salopek, R. (2005). Uputa za upravljanje $i$ rukovanje dizel-hidrauličnom lokomotivom HŽ serije 2132 300. Tvornica Željezničkih vozila Gredelj, Zagreb

[4] Ujaković, N. (2012). Strojarski dio vučnih vozila II. Tehnička škola Zagreb

[5] Adamović, Ž., Stanković, N., \& Savić, B. (2011). Pouzdanost mašina i postrojenja; Novi Sad, AMB Grafika.

[6] Weidauer J. (2011). Električna pogonska tehnika, Zagreb Graphis d.o.o.

[7] www.ss-strukovna-vvlatkovica-zd.skole.hr, Dijagnostika i održavanje uređaja.

[8] Kondić, Ž., Čikić, A., \& Kondić, V. (2014). Osnove održavanja mehatroničkih sustava 1. 1. izd. Bjelovar; Visoka Tehnička Škola u Bjelovaru.

[9] Filipović, S., Vasić, M., Tica, S., Veg, E. \& Šiniković, G. (2020). Using Modified Nadler-Tushman Model in GAP
Analysis of Educational Process of EFMNS Certified Engineer. Tehnicki vjesnik-Technical gazette, 27 (4), 12131220. https://doi.org/10.17559/TV-20190530215022

[10] Schindlerová, V., Šajdlerová, I., Michalčík, V., Nevima, J. \& Krejčí, L. (2020). Potential of Using TPM to Increase the Efficiency of Production Processes. Tehnicki vjesnikTechnical gazette, 27 (3), 737-743. https://doi.org/10.17559/TV-20190328130749

[11] http://www.plant-maintenance.com/RCM-intro.shtml (09.03.2010)

[12] Failure mode and effects analysis-FMEA, http://www.weibull.com/basics/fmea.htm

[13] Fault Tree Analysis, Reliability Block Diagrams and the Block Sim FTI Edition,

[14] http://www.weibull.com/SystemRelWeb/ fault_tree_analysis_reliability_block_diagrams_and_the_bl ocksim fti edition.htm

[15] Basic Gates, http://www.weibull.com/SystemRelWeb/basic_gates.htm

[16] Mikulić, D., Mahalec, I., Koroman, V., \& Bazijanac, E. (2002). Koncept jednog goriva za vojna vozila. Zbornik radova $V$. međunarodni znanstveni $i$ stručni skup "Motori $i$ vozila 2002", Stepanić, Josip (ur.), Zagreb: FSB.

[17] Hunjak, T. \& Jakovčević, D. (2003). Višekriterijski modeli za rangiranje i uspoređivanje banaka. Zbornik Ekonomskog fakulteta u Zagrebu, 1(1).

[18] Pang, J., Wang, R., Xiao, Q. \& Qin, F. (2020). A DataDriven Condition Monitoring of Product Quality Analysis System Based on RS and AHP. Tehnicki vjesnik-Technical gazette, 27 (2), 382-390. https://doi.org/10.17559/TV20190828170533

[19] Begičević, N. (2008). Višekriterijski model odlučivanja u strateškom planiranju uvođenja e-učenja. Doktorska disertacija, Fakultet organizacije i informatike, Varaždin.

[20] Kadoić, N. (2018). Nova metoda za analizu složenih problema odlučivanja temeljena na analitičkom mrežnom procesu i analizi društvenih mreža. Doktorski rad, Fakultet organizacije i informatike, Zagreb

[21] Aleksi, I. \& Hocenski, Ž. (2009). Primjena Expert-Choice alata i AHP metode za odabir Virtex-5 FPGA čipa. Elaborat, Elektrotehnički fakultet u Osijeku.

[22] Lisjak, D. (2011). Primjena AHP-metode kao alata za optimalni izbor opreme. Održavanje u sustavu gospodarenja fizičkom imovinom. Hrvatsko društvo održavatelja

[23] Program Expert Choice: http://www.expertchoice.com

[24] Zeppelin Power Systems: https://www.zeppelinpowersystems.com/en/

\section{Contact information:}

Ivan PETROVIĆ, mag. ing. el.

(Corresponding author)

Saint Jean Industies d.0.o.

35000 SlavonskiBrod, Croatia

E-mail: ipetrovic81@gmail.com

\section{Željko HEDERIĆ, PhD}

J. J. Strossmayer University of Osijek, FERIT,

Kneza Trpimira 2B, 31000 Osijek

E-mail: hederic@ferit.hr

\section{Marinko STOJKOV, PhD}

University of Slavonski Brod, Mechanical Engineering Faculty in Slavonski Brod, Trg Ivane Brlić Mažuranić 2, 35000 Slavonski Brod, Croatia

E-mail: mstojkov@unisb.hr

Ivan SAMARDŽlĆ, PhD

University of Slavonski Brod, Mechanical Engineering Faculty in Slavonski Brod, Trg Ivane Brlić Mažuranić 2, 35000 Slavonski Brod, Croatia

E-mail: iamardzic@unisb.hr 